\title{
EFFECTS OF DIETARY CHROMIUM TRIPICOLINATE AND LYSINE ON GROWTH PERFORMANCE, CARCASS TRAITS, AND PLASMA METABOLITE LEVELS IN PIGS
}

\author{
E. K. AMOIKON ${ }^{1}$, T. L. WARD ${ }^{2}$ and L. L. SOUTHERN ${ }^{2}$ \\ 1'Laboratoire de Nutrition et Pharmacologie - UFR Biosciences, Université de Cocody, BP 582 Abidjan 22, Côte d'Ivoire \\ ${ }^{2}$ Department of Animal Science, Louisiana State University Agricultural Center, Baton Rouge, 70803 USA.
}

\begin{abstract}
An experiment was conducted to evaluate the effects of chromium tripicolinate (CrPic) and three levels of lysine in growing-finishing pigs. Average initial weight was $24.10 \mathrm{~kg}$. Six treatments were replicated four times with four pigs per replicate. Three basal corn-soybean meal diets (B1 : $80 \%$ National Research Council (NRC, 1988) lys level ; B2 : $120 \%$ NRC lys level ; and B3 : $160 \%$ NRC lys level) with three main diets supplemented with $200 \mathrm{ppb}$ of $\mathrm{Cr}$ from CrPic (B1+200 ppb Cr, B2 $+200 \mathrm{ppb} \mathrm{Cr}$ and B3 $+200 \mathrm{ppb} \mathrm{Cr}$ ). During the growing phase, daily weight gain was decreased by chromium tripicolinate $(p<0.04)$, without any effect on total growth performance and carcass traits. $\mathrm{CrPic}$ decreased pre-prandial state urea nitrogen values $(p<.003)$ and increased post-prandial state urea nitrogen values $(p<0.02)$. On the other hand, lysine levels increased feed efficiency (Lysine linear, $p<0.08$ ) in growing pigs. Lysine increased loin eye area (lysine linear, $p<0.05$; lysine quadratic, $p<0.05$ ), but decreased tenth rib fat (lysine linear, $p<0.03$; lysine quadratic, $p<0.009$ ). Cholesterol values were decreased by lysine levels under pre-prandial state (lysine linear, $p<0.02$; lysine quadratic, $p<0.08$ ), and under post-prandial state (lysine linear, $p<0.02$; lysine quadratic, $p<0.005$ ). At the end of the trial, values of non-esterified fatty acids (NEFA) were elevated by lysine (lysine quadratic, $p<0.08$ ), and so were those of total proteins (lysine quadratic, $p<0.02$ ). Urea nitrogen values were elevated by lysine increment 19 (linear effect of lysine; $p<0.0002$ ). CrPic and lysine interaction was shown on NEFA and 20 urea nitrogen values. These results show that CrPic has minimal effects on growth efficiency, while lysine affects significantly growth performance, carcass characteristics and most of plasma metabolites in growing-finishing pigs.
\end{abstract}

Key-words : Pig, chromium, lysine, growth, metabolites, USA.

\section{RESUME}

EFFETS DU TRIPICOLINATE DE CHROME ET DE LA LYSINE SUR LA CROISSANCE, LA CARCASSE ET LES TAUX DES METABOLITES PLASMATIQUES CHEZ LES PORCS.

Une expérience a été conduite afin d'évaluer l'effet du tripicolinate de chrome (CrPic) et de trois taux de lysine chez des porcs, de la phase de croissance à la phase de finition. Le poids corporel initial des animaux était de $24,11 \mathrm{~kg}$. Six traitements ont été répétés quatre fois, avec quatre porcs par répétition. Au cours de cette expérience, les animaux ont été soumis à trois régimes alimentaires de base, contenant un mélange de maïs et de soja (B1 : 80 \% du taux de lys recommandé par National Research Council (NRC.1988) ; B2 : $120 \%$ du taux de lys (NRC) et B3 : $160 \%$ du taux de lys (NRC)), plus trois régimes de base enrichis avec 200 ppb de chrome sous forme de CrPic (B1+200 ppb de Cr, B2+200 ppb de Cr et B3+200 ppb de Cr). Pendant la phase de croissance, le gain quotidien de poids corporel était réduit par le tripicolinate de chrome $(p<0,04)$, sans aucun effet sur la croissance pondérale totale et les caractéristiques de la carcasse. Les résultats obtenus indiquent que le CrPic entraîne une diminution des concentrations plasmatiques de l'azote de l'urée $(p<0,003)$ chez les animaux en état pré-prandial et une augmentation des concentrations plasmatiques de l'azote de l'urée chez les mêmes animaux, mais en état post-prandial $(p<0,02)$. Les taux de lys ont provoqué une augmentation du coefficient d'efficacité de croissance (lys linéaire, $p<0,08$ ) chez les porcs pendant la phase de croissance. La lysine a augmenté le tissu maigre de la côtelette au niveau de la $10^{\circ}$ paire de côtes (lys linéaire, $p<0,05$; lys quadratique, $p<0,05$ ). Les taux de lys ont diminué la masse de tissu 
gras de la côtelette au niveau de la 10 paire de côtes (lys linéaire, $p<0,03$; lys quadratique, $p<0,009$ ). Les taux plasmatiques de cholestérol ont été réduits par le taux de lysine chez les animaux en état pré-prandial (lys linéaire, $p<0,02$; lys quadratique, $p<0,08$ ), et en état post-prandial (lys linéaire, $p<0,02$; lys quadratique, $p<0,005)$. A la fin de l'essai, les taux des acides gras non estérifiés ont été élevés parla lysine (lys quadratique, $p<0,08$ ), de même que ceux des protéines totales (lys quadratique, $p<0,02$ ). Les valeurs de l'azote de l'urée étaient également élevées par la lysine (lys linéaire, $p<0,0002$ ). L'effet de l'interaction de CrPic et de la lysine a été plus marqué sur les concentrations des acides gras non estérifiés et celles de l'azote de l'urée. Ces résultats indiquent que le picolinate de chrome a très peu d'effets sur la croissance, alors que la lysine altère significativement la croissance, les caractéristiques de la carcasse et les valeurs des métabolites plasmatiques des porcs.

Mots-Clés : Porc, chrome, lysine, croissance, métabolites, USA.

\section{INTRODUCTION}

The potential capability of lysine to improve growth performance and carcass composition of growing pigs is well established, since lysine is one of the limiting amino acids in the growth of swine (NRC, 1988). Dubroff et al. (1979) showed that diets supplemented with lysine and tryptophane induced an improved growth in swine. Colin et al. (1975) reported that low levels of lysine in the drinking water consumption improved considerably growth rate and growth efficiency in rabbits under lysine deficiency. On the contrary, the efficacy of dietary chromium (chromium picolinate) on animal productivity has not been broadly investigated. Jensen et al. (1977) determined that chromium increased muscle rate and decreased fat in poultry and in pigs. Page et al. (1993a), and Kornegay et al. (1997) reported an increased longissimus muscle area and a decreased backfat of carcass when chromium picolinate was fed to growing-finishing pigs. But, these findings have not been corroborated by other studies (Mooney and Cromwell, 1995 ; Crow and New-Comb, 1997). Since currently, the National Research Council (NRC, 1988) does not recommend dietary chromium supplementation for swine, the goal of this work, is to find out if lysine can potentiate the effect of minute amount of dietary chromium tripicolinate (200 ppb of $\mathrm{Cr}$ ) on growth performance, carcass composition and plasma metabolites in growing-finishing pigs.

\section{MATERIAL AND METHODS}

This experiment was conducted with growingfinishing pigs. Three corn-soybean meal basal diets (B1, B2, B3) with $0 \mathrm{ppb}$ of $\mathrm{Cr}$ containing
80,120 and $160 \%$ of lysine (NRC 1988, lysine requirements) respectively, and three other diets made of the basal diets supplemented with $200 \mathrm{ppb}$ of $\mathrm{Cr}$ (chromium tripicolinate ; $12 \% \mathrm{Cr}$, Nutrition 21, San Diego, CA).

\section{ANIMALS USED}

The pigs used are crossbred (Yorkshire Hampshire Duroc) growing-finishing pigs born and raised at Louisiana State University Agricultural Center Swine Unit in Baton Rouge (La, USA). There were 54 barrows and 42 gilts, penned in total confinement on total slatted floors in $1.8 \times 2.4 \mathrm{~m}$ pens during the growing period and in an open front building with a solid concrete floor in $1.5 \times 6.1 \mathrm{~m}$ pens during the finishing period. Two gilts died during the growing phase. Randomised complete blocked designs were used and pigs were allotted to treatments on the basis of weight, ancestry and sex. All treatments were replicated four times with four pigs per replicate. The average initial weight (IW) and final weight (FW) were $24.10 \mathrm{~kg}$ and $104.90 \mathrm{~kg}$, respectively. The growing pigs weighed between $20 \mathrm{~kg}$ and $50 \mathrm{~kg}$. The finishing pigs weighed between $50 \mathrm{~kg}$ and $100 \mathrm{~kg}$. Experimental periods were 83.97 and 111 days, according to the times animals reached $100 \mathrm{~kg}$. Weight gain and feed consumption were recorded every two weeks until the end of the experiment. Pigs were allowed ad libitum access to the experimental diets and tap water. The corn-soybean diets used were formulated to contain 80,120 and $160 \%$ of the lysine requirement (NRC, 1988) for growing (Table 1) and finishing pigs (Table 2). All diets met or exceeded the requirement of all other nutrients. Pigs were slaughtered at three different periods (after 83. 97 and 111 days of trial). 
Table 1 : Composition of grower diet $(\%)^{\mathrm{a}}$.

Composition des aliments de porc en phase de croissance.

\begin{tabular}{|c|c|c|c|c|c|c|}
\hline \multirow[b]{2}{*}{ Ingredients } & \multicolumn{6}{|c|}{ Different diet } \\
\hline & B1 & B2 & B3 & $\mathrm{B} 1+\mathrm{Cr}$ & $\mathrm{B} 2+\mathrm{Cr}$ & $\mathrm{B} 3+\mathrm{Cr}$ \\
\hline Corn & 84.10 & 72.90 & 61.71 & 83.10 & 71.90 & 60.71 \\
\hline Soybean meal & 13.44 & 24.75 & 36.06 & 13.44 & 24.75 & 36.06 \\
\hline D. R. P. & 1.54 & 1.31 & 1.07 & 1.54 & 1.31 & 1.07 \\
\hline Limestone & 0.37 & 0.49 & 0.61 & 0.37 & 0.49 & 0.61 \\
\hline LSU Vitamins ${ }^{\mathrm{b}}$ & 0.25 & 0.25 & 0.25 & 0.25 & 0.25 & 0.25 \\
\hline LSU Trace minerals $^{c}$ & 0.30 & 0.30 & 0.30 & 0.30 & 0.30 & 0.30 \\
\hline Premix & $\ldots$ & $\ldots$ & $\ldots$ & 1.00 & 1.00 & 1.00 \\
\hline Total & 100 & 100 & 100 & 100 & 100 & 100 \\
\hline
\end{tabular}

B2: $17: B 3: 21 ;$ lys : B1:0.60:B2:0.92:B3:120:Ca:0.70:P:0.60.

D. R. P. = Defluorinated Rock Phosphate.

${ }^{b}$ Provided the following per kilogram of diet : riboflavin, $4.4 \mathrm{mg}$; d-pantothenic acid, $22 \mathrm{mg}$; niacin, $22 \mathrm{mg}$; vitamin B12, $22 \mathrm{~g}$; d-biotin, $220 \mathrm{~g}$; choline chloride, $440 \mathrm{mg}$; vitamin A, 4,400 IU ; vitamin D3, $440 \mathrm{IU}$; vitamin E, $11 \mathrm{IU}$; menadione (as menadione dimethylprimidinol bisulfite), $0.25 \mathrm{mg}$; Se, $0.1 \mathrm{mg}$

'Provided the following per kilogram of diet : Zn, $75 \mathrm{mg} ; \mathrm{Fe}, 87.5 \mathrm{mg} ; \mathrm{Mn}, 30 \mathrm{mg} ; \mathrm{Cu}, .8 .75 \mathrm{mg} ; \mathrm{I}, 1 \mathrm{mg} ; \mathrm{Ca}, 9 \mathrm{mg}$.

Table 2 : Composition of finisher diet (\%)

Composition des aliments de porc en phase de croissance.

\begin{tabular}{|c|c|c|c|c|c|c|}
\hline \multirow[b]{2}{*}{ Ingredients } & \multicolumn{6}{|c|}{ Differents diets } \\
\hline & B1 & B2 & B3 & $\mathrm{B} 1+\mathrm{Cr}$ & $\mathrm{B} 2+\mathrm{Cr}$ & $\mathrm{B} 3+\mathrm{Cr}$ \\
\hline Corn & 88.96 & 80.00 & 71.05 & 87.96 & 79.00 & 70.05 \\
\hline Soybean meal & 8.88 & 17.93 & 26.98 & 8.88 & 17.93 & 26.98 \\
\hline D. R. P. & 1.07 & 0.89 & 0.72 & 1.07 & 0.89 & 0.72 \\
\hline Limestone & 0.54 & 0.63 & 0.70 & 0.54 & 0.63 & 0.70 \\
\hline LSU Vitamins ${ }^{\text {b }}$ & 0.25 & 0.25 & 0.25 & 0.25 & 0.25 & 0.25 \\
\hline LSU Trace minerals ${ }^{c}$ & 0.30 & 0.30 & 0.30 & 0.30 & 0.30 & 0.30 \\
\hline Premix & $\ldots$. & $\ldots$ & $\ldots$ & 1.00 & 1.00 & 1.00 \\
\hline Total & 100 & 100 & 100 & 100 & 100 & 100 \\
\hline
\end{tabular}

aCalculated composition : CP : B1, $11.50 \%$, B2, $14.70 \%$; B3, $17.90 \%$; lysine : B1, $0.50 \%$; B2, $0.72 \%$; B3, $0.90 \%$; Ca, $0.60 \%$; P, .50\%.

D. R. P. = Defluorinated Rock Phosphate.

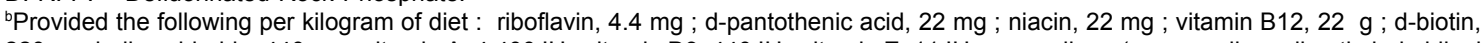
$220 \mathrm{~g}$; choline chloride, $440 \mathrm{mg}$; vitamin A, 4,400 IU ; vitamin D3, $440 \mathrm{IU}$; vitamin E, $11 \mathrm{IU}$; menadione (as menadione dimethylprimidinol bisulfite), $0.25 \mathrm{mg}$; Se, $0.1 \mathrm{mg}$.

'Provided the following per kilogram of diet : Zn, $75 \mathrm{mg}$; Fe, $87.5 \mathrm{mg} ; \mathrm{Mn}, 30 \mathrm{mg} ; \mathrm{Cu}, 8.75 \mathrm{mg} ; \mathrm{I}, 1 \mathrm{mg} ; \mathrm{Ca}, 9 \mathrm{mg}$.

\section{CARCASS EVALUATION}

Upon termination of the trial, all pigs were slaughtered in a commercial facility and hot carcass weight $(\mathrm{CW})$ were obtained for dressing percentage (DP) calculation. Selected carcass measurements were obtained following a $24 \mathrm{~h}$ chill at $2{ }^{\circ} \mathrm{C}$. Fat thickness over the longissimus muscle at the tenth rib (TRF) and loin eye area (LEA) were obtained by tracing the longissimus muscle surface at the tenth rib fat, and were adjusted to $104.90 \mathrm{~kg}$ of body weight, by methods approved by the NSIF (1988). Percentage of muscling (PM) was calculated with the National Pork Producers Council method (NPPC, 1988).

\section{BLOOD ANALYSES}

Blood samples were collected from each pig at three different times. Blood was collected on $14 \mathrm{~h}$-fasting pigs (pre-prandial state) for plasma metabolites analyses. Then pigs were allowed to consume feed ad libitum for $3 \mathrm{~h}$ before bleeding them again (post-prandial state). At the end of the trial (average body weight $=104.90 \mathrm{~kg}$ ), blood was collected from $14 \mathrm{~h}$-fasting pigs before slaughtering. All blood samples were obtained via the anterior vena cava. For each time, $6 \mathrm{ml}$ of blood were collected and divided into two tubes for hormone (insulin) assay and for metabolites analyses. Collected blood was centrifuged at $1,020 \mathrm{~g}$ for $20 \mathrm{~min}$ at $4{ }^{\circ} \mathrm{C}$, and plasma samples kept in a freezer $\left(4^{\circ} \mathrm{C}\right)$ until analyses. Plasma was analyzed for glucose (Sigma, 1990), cholesterol (Sigma, 1989a), and total proteins (Sigma, 1989b) concentrations, using spectrophotometric procedure outlined in commercially available kits (Sigma chemical). Plasma urea nitrogen (urea $\mathrm{N}$ ) concentrations were determined spectrophotometrically using the urease procedure outlined by Fernandez et al. (1988). Plasma Non-Esterified Fatty acids (NEFA) concentrations were determined using 
a commercial enzymatic procedure (NEFA6Ckit, ACS-ACOD Method; Wako Chemicals USA, Richmond, VA). All samples were assayed in duplicate and measurements resulting in errors greater than $5 \%$ were reanalyzed. Plasma insulin was assayed by RIA method of Fernandez et al. (1988). Guinea pigs anti-bovine insulin antiserum (code $\mathrm{N}^{\circ} 65-101$, lot $\mathrm{N}^{\circ} \mathrm{GP616}$; ICN ImmunoBiologicals, Lisle, IL) was used at $1: 60.000$ final dilution. Purified porcine insuline $(26.1 \mu \mathrm{U} / \mathrm{ng}$; Sigma chemical) and bovine (125 I) insulin (ICN Biomedicals, Costa Mesa, CA) were used as the standard and radio ligand, respectively. Sheep anti-guinea pig antiserum produced in our laboratory was used at $1: 4$ dilution as the precipitating antibody. The intraassay and interassay $\mathrm{CV}$ for the insulin RIA as determined by pooled bovine plasma samples were $14 \%$ and $13 \%$, respectively.

\section{STATISTICALANALYSES}

All data were analysed by ANOVA (Steel and Torrie, 1980) using GLM procedures of SAS (1985), in a randomized complete blocks with the pen of pigs as the experiment unit. The experiment was a complete $3 \times 2$ factorial arrangement. Basal diets were supplemented with $0 \mathrm{ppb}$ or $200 \mathrm{ppb}$ of chromium and lysine levels $(80,120,160 \%)$ were separated equally so that linear and quadratic contrasts were used to evaluate lysine treatment effect. Mean values are expressed as LSM, and standard error on the mean as SEM.

\section{RESULTS}

\section{EFFECT OF CHROMIUM TRIPICOLINATE ON GROWTH PERFORMANCE}

During the growing phase, daily gain (Table 3 ) was decreased by chromium picolinate $(p<0.04)$ without any effect on feed efficiency $(\mathrm{G} / \mathrm{F})$. But, CrPic had no effect on growth performance of finishing and growing-finishing pigs (Table 4, Table 5), and carcass characteristics (Table 6). CrPic decreased pre-prandial state urea nitrogen values $(p<0.003$. Table 7$)$ and increased postprandial state urea nitrogen values $(p<0.02$, Table 8).

Table 3 : Mean values of daily gain (ADG), feed intake (ADFI), and gain/feed (G/F) of growing pigs fed with dietary chromium and lysine ${ }^{\mathrm{a}}$.

Moyennes des gains en poids et consommation journaliers, et ratio gain/consommation des porcs en phase de croissance nourris au $\mathrm{Cr}$ et au Lysine.

\begin{tabular}{lccccccc}
\hline Item & $\mathrm{B} 1$ & $\mathrm{~B} 2$ & $\mathrm{~B} 3$ & $\mathrm{~B} 1+\mathrm{Cr}$ & $\mathrm{B} 2+\mathrm{Cr}$ & $\mathrm{B} 3+\mathrm{Cr}$ & $\mathrm{SEM}$ \\
\hline ADG $\left(\mathrm{kg}^{\mathrm{b}}\right)$ & 0.76 & 0.87 & 0.85 & 0.73 & 0.80 & 0.81 & 0.02 \\
$\mathrm{ADFI}(\mathrm{kg})$ & 2.25 & 2.56 & 2.25 & 2.35 & 2.23 & 2.21 & 0.16 \\
${\mathrm{G} / \mathrm{F}^{\mathrm{c}}}^{\mathrm{C}}$ & 0.34 & 0.35 & 0.38 & 0.32 & 0.36 & 0.37 & 0.02 \\
\hline
\end{tabular}

aMeans (LSM) of four replicates with four pigs per replicate

${ }^{b}$ Effect of CrPic $(p<0.04)$; linear effect of lys $(p<0.005)$; quadratic effect of lys $(p<0.04)$

cLinear effect of lys $(p<0.08)$

Tableau 4 : Mean values of daily gain (ADG), feed intake (ADFI), and gain/feed (G/F) of finishing pigs fed with dietary CrPic and lysine ${ }^{\mathrm{a}}$.

Moyennes des gains en poids et consommation journaliers, et ratio gain/consommation des porcs en phase de finition nourris au Cr et au Lysine.

\begin{tabular}{lccccccc}
\hline Item & $\mathrm{B} 1$ & $\mathrm{~B} 2$ & $\mathrm{~B} 3$ & $\mathrm{~B} 1+\mathrm{Cr}$ & $\mathrm{B} 2+\mathrm{Cr}$ & $\mathrm{B} 3+\mathrm{Cr}$ & $\mathrm{SEM}$ \\
\hline $\mathrm{ADG}(\mathrm{kg})$ & 0.83 & 0.93 & 0.88 & 0.88 & 0.88 & 0.89 & 0.03 \\
ADFI (kg) & 3.19 & 3.37 & 3.36 & 3.36 & 3.28 & 3.35 & 0.09 \\
${\mathrm{G} / \mathrm{F}^{c}}^{\mathrm{c}}$ & 0.26 & 0.28 & 0.26 & 0.26 & 0.27 & 0.27 & 0.01 \\
\hline
\end{tabular}

a Data are means (LSM) of four replicates with four pigs per replicate

No effect of CrPic or lys on mean values of ADG, ADFI, and G/F was observed $(p>0.10)$ 
Table 5 : Mean values of daily gain (ADG), feed intake (ADFI), and gain/feed (G/F) of growing-finishing pigs fed with dietary CrPic and lysine. ${ }^{\text {a }}$

Moyennes des gains en poids et consommation journaliers, et ratio gain/consommation des porcs de la phase de croissance à la phase de finition nourris au Cr et au Lysine.

\begin{tabular}{lccccccc}
\hline Item & B1 & B2 & B3 & B1+Cr & B2+Cr & B3+Cr & SEM \\
\hline IW $(\mathrm{kg})$ & 24.18 & 24.36 & 23.47 & 24.47 & 24.32 & 23.87 & 0.34 \\
FW $(\mathrm{kg})$ & 104.05 & 102.38 & 107.19 & 109.00 & 103.25 & 103.51 & 2.63 \\
ADG $\left(\mathrm{kg}^{\mathrm{b}}\right)$ & 0.80 & 0.90 & 0.87 & 0.82 & 0.85 & 0.85 & 0.02 \\
ADFI $(\mathrm{kg})_{\mathrm{G}^{\mathrm{F}} \mathrm{F}^{\mathrm{c}}}^{2.80}$ & 2.99 & 2.89 & 2.94 & 2.81 & 2.86 & 0.09 \\
\hline
\end{tabular}

aData are means (LSM) of four replicates with four pigs per replicate

binear effect of lys $(P<.03)$; quadratic effect of lys $(p<0.04)$

Tableau 6 : Mean values of some carcass characteristics of growing-finishing pigs fed with dietary CrPic and lysine ${ }^{a}$.

Moyennes des gains en poids et consommation journaliers, et ratio gain/consommation des porcs de la phase de croissance à la phase de finition nourris au Cr et au Lysine.

\begin{tabular}{lccccccc}
\hline Item & B1 & B2 & B3 & B1+Cr & B2+Cr & B3+Cr & SEM \\
\hline LEA $\left(\mathrm{cm}^{2}\right)^{\mathrm{b}}$ & 28.06 & 32.27 & 30.45 & 27.80 & 30.02 & 30.12 & 1.06 \\
TRF $^{\mathrm{c}}(\mathrm{cm})^{\mathrm{c}}$ & 3.49 & 2.79 & 3.09 & 3.41 & 2.99 & 3.08 & 0.14 \\
PM $^{\mathrm{d}}$ & 42.92 & 47.39 & 45.04 & 42.71 & 45.71 & 45.28 & 0.82 \\
$\mathrm{CW}^{(\mathrm{kg})}$ & 80.72 & 77.62 & 81.48 & 84.34 & 77.88 & 79.24 & 2.72 \\
DP $^{\mathrm{e}}$ & 77.70 & 76.39 & 75.39 & 76.23 & 75.77 & 76.84 & 0.54 \\
\hline
\end{tabular}

${ }^{a}$ Data are means (LSM) of four replicates with four pigs per replicate

bLinear effect of lysine $(p<0,05)$; quadratic effect of lysine $(p<0.05)$

cLinear effect of lysine $(p<0,03)$; quadratic effect of lysine $(p<0.009)$

dinear effect of lysine $(p<0,02)$; quadratic effect of lysine $(p<0.003)$

eLinear interaction effect of $\mathrm{Cr}{ }^{*}$ Lys $(\mathrm{p}<0.03)$

\section{EFFECT OF LYSINE ON GROWTH PERFORMANCE}

Lysine levels increased daily weight gain (lysine linear, $p<0.005$; lysine quadratic, $p<0.04$ ) and feed efficiency (lysine linear, $p<.08$ ) in growing pigs (Table 3 ) but had no effect on growth performance of finishing pigs $(p>0.10$; Table 4). Overall average daily weight gain was increased by lysine levels at the end of the trial (lysine linear, $p<0.03$; lysine quadratic, $p<0.04$, Table 5). Table 6 shows that lysine levels increased loin eye area (LEA) (lysine linear, $p<0.05$; lysine quadratic, $p<0.05$ ), percentage of muscling (PM) (lysine linear, $p<0.02$; lysine quadratic, $p<0.003)$. On the contrary, lysine levels decreased tenth rib fat (TRF) (lysine linear, $p<0.03$; lysine quadratic, $p<0.009$ ), carcass weight (CW) (not significant) and dressing percentage (DP, not significant). Glucose levels were decreased by lysine addition under post-prandial state (lysine linear, $p<0.08$; lysine quadratic, $p<0.09$ ) (Table 8). Cholesterol values were also decreased by lysine levels under pre-prandial state (lysine linear, $p<0.02$; lysine quadratic, $p<0.08$, Table 7), under post-prandial state (lysine linear, $p<0.02$; lysine quadratic, $p<0.005$, Table 8 ) and before slaughtering (not significant, Table 9). At the end of the trial (Table 9), values of non-esterified fatty acids (NEFA) were elevated by lysine (lysine quadratic, $p<0.08)$, and so were those of total proteins (lysine quadratic, $p<0.02$ ). Urea nitrogen values were elevated by lysine increment in pre-prandial state animals (lysine linear, $p<0.0002$; lysine quadratic, $P<0.05$, Table 7), post-prandial state animals (lysine linear, $p<0.0002$, Table 8) and animals at slaughtering (lysine linear, $p<0.0002$, Table 9). Insulin levels were increased by lysine (lysine quadratic, $p<0.02$, Table 9).

\section{INTERACTION EFFECT OF CHROMIUM TRIPICOLINATE AND LYSINE ON GROWTH PERFORMANCE}

There was no interaction effect of $\mathrm{CrPic}$ and lysine on growth performance and most of carcass characteristics of the animals $(p>0.10)$. A linear interaction effect of $\mathrm{CrPic}$ and lysine is reported in table 6 (CrPic $x$ lys, $p<0.03)$; this 
interaction decreased the dressing percentage (DP) values (lysine linear, $p<0.03$ ). Under preprandial state there was an interaction quadratic effect (lysine quadratic, $p<0.01$ ) which decreased plasma NEFA values of pigs. On the same animals, a linear interaction effect increased plasma urea nitrogen values (lysine linear, $p<0.06$ ) due to lysine effect (lysine linear, $p<0.0002$; lysine quadratic, $p<0.05$ ) on plasma urea nitrogen (Table 7).

Table 7 : Mean values of plasma metabolites of finishing pigs before feeding with dietary chromium and lysine (pre-prandial state) ${ }^{\mathrm{a}}$.

Taux de métabolites plasmatiques des porcs en phase de finition avant alimentation en chromium et lysine (état pré-prandial).

\begin{tabular}{|c|c|c|c|c|c|c|c|}
\hline Item & B1 & B2 & B3 & $\mathrm{B} 1+\mathrm{Cr}$ & $\mathrm{B} 2+\mathrm{Cr}$ & $\mathrm{B} 3+\mathrm{Cr}$ & SEM \\
\hline Glucose (mmol/L) & 4.52 & 4.19 & 4.50 & 4.54 & 4.46 & 4.36 & 0.11 \\
\hline Cholesterol $(\mathrm{mmol} / \mathrm{L})^{\mathrm{b}}$ & 99.49 & 86.02 & 89.49 & 95.25 & 90.12 & 88.45 & 3.02 \\
\hline $\operatorname{NEFA}(\mu \mathrm{Eq} / \mathrm{L})^{\mathrm{c}}$ & 297.11 & 394.92 & 255.78 & 352.74 & 261.59 & 337.02 & 39.38 \\
\hline Protein $(\mathrm{g} / \mathrm{L})$ & 55.64 & 56.81 & 56.13 & 55.61 & 57.85 & 56.13 & 1.02 \\
\hline Urea $\mathrm{N}(\mathrm{mmol} / \mathrm{L})^{\mathrm{d}}$ & 9.12 & 11.40 & 16.57 & 8.31 & 10.81 & 13.89 & 0.45 \\
\hline
\end{tabular}

a Data are means (LSM) of four replicates with four pigs per replicate

binear effect of lys $(p<0.02)$; quadratic effect of lys $(p<0.08)$

cNEFA=Non-Esterified Fatty Acids, Quadratic interaction effect of CrPic * Iys $(p<0.001)$

${ }^{d}$ CrPic effect $(P<.003)$; linear effect of lys $(P<.0002)$; quadratic effect of lys $\left.p<0.05\right)$; linear interaction

effect of CrPic * lys $(p<0.06)$

SEM : Standard Error on the Mean

Table 8 : Mean values of plasma metabolites of finishing pigs after feeding with dietary chromium and lysine (post-prandial state) ${ }^{\text {a }}$.

Taux de métabolites plasmatiques des porcs en phase de finition avant alimentation en chromium et lysine (état post-prandial).

\begin{tabular}{|c|c|c|c|c|c|c|c|}
\hline Item & B1 & B2 & B3 & $\mathrm{B} 1+\mathrm{Cr}$ & $\mathrm{B} 2+\mathrm{Cr}$ & $\mathrm{B} 3+\mathrm{Cr}$ & SEM \\
\hline Glucose $(\mathrm{mmol} / \mathrm{L})^{b}$ & 4.88 & 4.40 & 4.36 & 5.02 & 4.23 & 4.58 & 0.25 \\
\hline Cholesterol $(\mathrm{mmol} / \mathrm{L})^{\mathrm{c}}$ & 89.20 & 77.60 & 82.98 & 89.43 & 78.55 & 81.15 & 2.61 \\
\hline NEFA $(\mu \mathrm{Eq} / \mathrm{L})$ & 107.89 & 114.38 & 118.06 & 119.57 & 118.31 & 107.80 & 7.53 \\
\hline Protein $(\mathrm{g} / \mathrm{L})$ & 49.19 & 50.22 & 51.5 & 50.81 & 51.43 & 52.66 & 1.41 \\
\hline Urea N $(\mathrm{mmol} / \mathrm{L})^{\mathrm{d}}$ & 11.20 & 14.57 & 19.95 & 11.92 & 16.19 & 22.33 & 0.70 \\
\hline
\end{tabular}

aData are means (LSM) of four replicates with four pigs per replicate

binear effect of lys $(p<0.08)$; quadratic effect of lys $(p<0.09)$

cinear effect of lys $(p<0.02)$; quadratic effect of lys $(p<0.005)$

${ }^{d}$ CrPic effect $(p<0.02)$; linear effect of lys $(p<0.0002)$

SEM : Standard Error on the Mean

Table 9 : Mean values of plasma metabolites of growing-finishing pigs at slaughtera

Taux de métabolites plasmatiques des porcs à l'abattage.

\begin{tabular}{lccccccc}
\hline Item & B1 & B2 & B3 & B1+Cr & B2+Cr & B3+Cr & SEM \\
\hline Glucose $(\mathrm{mmol} / \mathrm{L})$ & 4.14 & 3.95 & 4.11 & 4.06 & 3.90 & 4.06 & 0.14 \\
Cholesterol $(\mathrm{mmol} / \mathrm{L})$ & 81.69 & 70.69 & 76.19 & 76.68 & 74.02 & 73.43 & 3.46 \\
NEFA $(\mu \mathrm{EQ} / \mathrm{L})^{\mathrm{b}}$ & 219.15 & 279.87 & 235.26 & 237.29 & 320.27 & 225.58 & 43.26 \\
Protein $(\mathrm{g} / \mathrm{L})^{\mathrm{c}}$ & 46.16 & 48.75 & 46.93 & 47.17 & 50.23 & 47.87 & 0.10 \\
${\text { Urea N }(\mathrm{mmol} / \mathrm{L})^{\mathrm{d}}}_{\text {Insulin }(\mu \mathrm{U} / \mathrm{mL})^{\mathrm{e}}}$ & 7.33 & 11.21 & 13.69 & 8.55 & 10.34 & 13.41 & 0.57 \\
& 10.64 & 7.93 & 14.14 & 12.15 & 7.38 & 14.22 & 2.20 \\
\hline
\end{tabular}

${ }^{\mathrm{a}} \mathrm{Data}$ are means (LSM) of four replicates with four pigs per replicate

${ }^{b}$ Quadratic effect of lys $(p<0.08)$

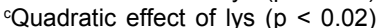

dLinear effect of lys ( $p<0.0002)$

eQuadratic effect of lys $(p<0.02)$

SEM : Standard Error on the Mean 


\section{DISCUSSION}

\section{EFFECT OF CHROMIUM TRIPICOLINATE ON GROWTH PERFORMANCE}

This investigation showed that $200 \mathrm{ppb}$ of chromium from CrPic supplementation of cornsoybean meal diets did not adversely affect carcass traits, feed efficiency, average daily feed intake of growing-finishing pigs. However, average daily gain, during the growing phase was reduced by $200 \mathrm{ppb}$ of Cr. Page et al. (1993a) who investigated on the effects of $\mathrm{CrPic}$ in pigs, did not find any significant effect of this trace mineral on $A D G, A D F I$ and G/F. They reported that the most striking effects of dietary CrPic on swine productivity were increased LEA and PM, and a decreased TRF. Positive effects of dietary Chromium have been demonstrated by Lindemann et al. (1995) in pigs. However, some other results published by Boleman et al. (1994), Mooney and Cromwell (1997), and Matthews et al. (2003) did not report any significant effect of Cron growth performance and body composition in pigs. Discrepancies observed in the evaluation of the effect of different kinds, and levels of $\mathrm{Cr}$ in pigs, inclined Ward et al. (1997) to determine a possible interactive effect of dietary chromium tripicolinate ( $400 \mathrm{ppb}$ of $\mathrm{Cr}$ ) and pen space as a stress in growing-finishing pigs. They concluded that pigs provided inadequate pen space had greater LEA and PM and lower TRF than pigs provided adequate pen space. Lindemann et al. (1995) suggested that some of the absence of effect of chromium may be explained by the initial weight at the time of supplementation, or the combination of body weight and the duration of trials. While in the present report, no effect of CrPic was noticed on cholesterol values, EvockClover et al. (1993) reported that supplemented dietary $\mathrm{CrPic}$ increased total cholesterol and high density lipoproteins (HDL)-cholesterol in pigs. Amoikon et al. (1995) indicated that dietary $\mathrm{Cr}$ as $\mathrm{CrPic}$ increased fasting plasma cholesterol. However, Riales and Albrink (1981), Mossop (1983) had reported that $\mathrm{Cr}$ supplementation decreased serum triglycerides and total cholesterol, and increased high-density lipoprotein cholesterol in diabetics. Page et al. (1993b) found that serum cholesterol was reduced by CrPic. Reduced levels of circulating total cholesterol have been also reported in calves fed CrPic (Bunting et al., 1994). Lindemann et al. (1995), and Matthews et al.
(2001) did not observe any effect of Cr on plasma cholesterol. Chromium is known to be efficient on lipids metabolism, despite some contradictory results, chromium seem to reduce cholesterol and triglycerides levels.

\section{EFFECT OF LYSINE ON GROWTH PERFORMANCE}

Increasing levels of lysine from crude protein affected positively growth efficiency, carcass characteristics and plasma metabolites of the pigs in this experience. These effects have already been reported by Ward et al. (1997) who found that $G / F$ was higher in pigs fed $120 \%$ than in pigs fed $80 \%$ of recommended lysine level. It was also reported by these authors that increasing the protein content of the diet from a deficient $(80 \%)$ to adequate lysine level $(120 \%)$ will improve longissimus muscle area and lower TRF thickness of the pigs. Lindemann et al. (1995) reported an improvement of G/F when $\mathrm{Cr}$ was supplemented to a diet providing $100 \%$ NRC (1988) lysine requirement estimates, but not with an excess of NRC (1988) lysine requirement. The results obtained in this experience corroborate those of Van de Ligt et al. (2002) who showed that increasing levels of lysine ( $76 \%, 83 \%, 90 \%$ of lysine requirement) increased linearly ADG, and that lysine level had a quadratic effect on TRF backfat thickness with the highest response at $83 \%$ of lysine level. In this work, it's reported the influence of lysine on ADG during the growing phase and at the end of the growing-finishing trial ; but not during the finition phase. Glucose levels were lowered by increasing levels of lysine after feeding. Such results were found by Van de Ligt et al. (2002) only before feeding animals. NEFA and insulin levels at the end of the trial were increased by lysine levels. Urea nitrogen values were increased by lysine levels in pre-feeding, postfeeding pigs and at slaughter. Lindemann et al. (1995), feeding pigs with $120 \%$ of lysine requirement showed that insulin levels and urea nitrogen values were increased, and NEFA values were lowered. These authors found also that lysine (protein) levels increased albumin levels, and lowered creatinine levels. Lysine is generally known to be beneficial for lean mass production. In swine, lysine, threonine and tryptophane have been investigated as limiting amino acids in cornsoybean meal diet. The requirement of these three limiting amino-acids is crucial, since they facilitate digestion and assimilation of proteins in general (NRC, 1988). 
INTERACTION EFFECT OF CHROMIUM TRIPICOLINATE AND LYSINE ON GROWTH PERFORMANCE

There were no interaction effects of lysine and chromium on growth performance. However, interaction effect was noted on DP, urea nitrogen, and NEFA values. The effect on plasma urea nitrogen values may be justified by $\mathrm{CrPic}$ and lysine which both altered this parameter. Van de Ligt et al. (2002) didn't observe any effect of Cr-Lys levels interaction on growth performance and carcass traits ; but, they found that Cr-Lys interaction resulted in improved G/F at the $100 \%$ of required lysine level, but not at the $120 \%$ of required lysine level (Lindemann et al., 1995).

\section{CONCLUSION}

Results of this experiment did not show any significant effect of $\mathrm{CrPic}$ on growth performance, carcass traits and plasma metabolites. On the contrary, Lysine improved growth efficiency, carcass characteristics and some plasma metabolites, with few $\mathrm{Cr}^{*}$ Lys interactions. To date, there is no doubt that chromium can improve carcass composition in humans, pigs and other animal species (rat, calf, lamb, and poultry).

However, some experiments have shown contradictory effects of this compound in pigs.

These changes in the effects of $\mathrm{Cr}$ can be explained by the animal models, the amounts of supplemented $\mathrm{Cr}$, the form of $\mathrm{Cr}$ and more interestingly, the initial body weight of animals during the experiments. Owing to the significant effect of chromium on tissue partionning in animals and humans, more research need to be done in order to elucidate its mechanism of action.

\section{REFERENCES}

Amoikon (E. K.), (J. M.) Fernandez, (L. L.) Southern, (D. L.) Thompson Jr., (T. L.) Ward, and (B. M.) Olcott. 1995. Effect of chromium tripicolinate on growth, glucose tolerance, Insulin sensitivity, plasma metabolites, and growth hormone in pigs. J. Anim. Sci. 73 : 1123-1130.

Boleman (S. L.), (S. J.) Boleman, (T. D.) Bidner, (T. L.) Ward, (L. L.) Southern, (M. M.) Pike and (J. E.) Pontif. 1994. Effect of chromium tripicolinate ( $\mathrm{CrPic})$ on growth, carcass composition, and sensory characteristics of growing-finishing pigs. J. Anim. Sci. 72 : (Suppl 1), 273. (Abstr.).

Bunting (L. D.), (J. M.) Fernandez, (D. L.) Thompson $\mathrm{Jr}$ and (L. L.) Southern. 1994. Influence of chromium picolinate on glucose usage and metabolic criteria in growing Holstein calves. J. Anim. Sci. 72 : 1591.

Colin (M.), (F.) Lebas et (A.) Delaveau. 1975. Influence d'un apport de lysine dans l'aliment solide ou dans l'eau de boisson sur les performances de croissance du lapin. Ann. Zootech. Vol. 24 ; № 2 : 315 - 321.

Crow (S. D.) and (M. D.) Newcomb. 1997. Effect of dietary chromium additions along with varying protein levels on growth performance and carcass characteristics of growing and finishing pigs. J. Anim. Sci. 75 (Suppl. 1) : 79 (Abstr.).

Dubroff (L. S.), Ward (C. O.) and (C. I.) Jarowski. 1979. Effect of dietary lysine and tryptophan supplementation on growth rate and toxicity of barbiturates and ethanol in rats. J. Pharm. Sci. Vol. 68 ; N¹, 2 : 1554 - 1557.

Evock-Clover (C. M.), (M. M.) Polansky, (R. A.) Anderson and (N. C.) Steele. 1993. Dietary chromium supplementation with or without somatotropin treatment alters serum hormones and metabolites in growing pigs without affecting growth performance, J. Nutr. $123: 1504$.

Fernandez (J. M.), (W. J.) Croom Jr, (A. D.) Johnson, (R. D.) Jaquette and (F. W.) Edens. 1988. Subclinical ammonia toxicity in steers : Effects on blood metabolites and regulatory hormones concentrations. J. Anim. Sci. 66 : 3259.

Jensen (L. S.), (D. V.) Maurice and (M. W.) Murray. 1977. Evidence for a new biological function of chromium. Federation Proceedings, 37, 404. Chromium picolinate additions to diets of growing / finishing pigs. J.Anim. Sci. 71 (Suppl 1) : (Abstr.).

Kornegay (E. T.), (Z.) Wang, (C. M.) Wood and (M. D.) Lindermann. 1997. Supplemental chromium picolinate influences nitrogen balance, dry matter digestibility, and carcass traits in growing-finishing pigs. J. Anim. Sci. 75 (5) : 1319 - 1323.

Lindemann (M. D.), (C. M.) Wood, (A. F.) Harper, (E. T.) Kornegay and (R. A.) Anderson 1995. Dietary chromium picolinate additions improve gain : feed and carcass characteristics in growing-finishing pigs and increase litter size in reproducing sows. J. Anim. Sci. 73 (2) : 457 - 465. 
Matthews (J. O.), (L. L.) Southern, (J. M.) Fernandez, (J. E.) Pontif, (T. D.) Bidner and (R. L.) Odgaard. 2001. Effect of chromium picolinate and chromium propionate on glucose and insulin kinetics of growing barrows and on growth and carcass traits of growing-finishing barrows. J. Anim. Sci. $79: 2172$ - 2178.

Matthews (J. O.), (A. D.) Higbie, (L. L.) Southern, (D. F.) Combs, (T. D.) Bidner and (R. L.) Odgaard. 2003. Effect of chromium propionate and metabolizable energy on growth, carcass traits, and pork quality of growing-finishing pigs. J. Anim. Sci. 81 : 191 - 196.

Mooney (K. W.) and (G. L.) Cromwell. 1995. Effects of dietary chromium picolinate supplementation on growth, carcass characteristics, and accretion rates of carcass tissues in growing-finishing swine. J. Anim. Sci. 73 : 3351 - 3357.

Mooney (K. W.) and (G. L.) Cromwell. 1997. Efficacy of chromium picolinate and chromium chloride as potential carcass modifiers in swine. J. Anim. Sci. 75 (10) : 2661 - 2671.

Mossop (R. T.). 1983. Effects of chromium III on fasting blood glucose, cholesterol and cholesterol HDL in diabetics. Centr. Afr. J. Med. $29: 80$.

NPPC. National Pork Producers Council (1988). Procedures to evaluate Market Hog Performance (2nd Ed). Des Moines, IA.

NRC. 1988. Nutrient Requirements of Swine $\left(9^{\text {th }}\right.$ Edition). National Academy Press, Washington, DC.

NSIF. (1988). Guidelines for uniform Swine Improvement programs. National Swine Improvement Federation. Washington, DC.

Page (T. G.), (L. L.) Southern, (J. E.) Pontif and (T. L.) Ward. 1993a. Effect of chromium tripicolinate or chromium chloride on growth, carcass traits, and plasma metabolites of growing-finishing pigs. In : Proc. XV Int. Cong. of Nutrition. Sept 26-Oct
1, 1993, Adelaide, Australia. Vol 1. : 199 (Abstr.).

Page (T. G.), (L. L.) Southern, (T. L.) Ward and (D. L.) Thompson Jr. 1993b. Effect of chromium picolinate on growth and serum and carcass traits of growing-finishing pigs. J. Anim. Sci. $71: 656$.

Riales (R.) And (M. J.) Albrink. 1981. Effect of chromium chloride supplementation on glucose tolerance and serum lipids including high-density lipoprotein of adult men. Am. J. Clin. Nutr. $34: 2670$.

SAS. (1985). SAS User's Guide : Statistics (Version $\left.5^{\text {th }} \mathrm{Ed}\right)$. SAS Inst Inc, Cary, NC.

Sigma (1989a). Cholesterol. Quantitative, enzymatic determination of total cholesterol in serum or plasma at $500 \mathrm{~nm}$., Sigma chemical Co, St. Louis, MO, Tech. Bull. $\mathrm{N}^{\circ}$ 352.

Sigma (1989b). Total protein. Quantitative, colorimetric determination in serum or plasma at $540 \mathrm{~nm}$. Sigma chemical Co, St. Louis, MO, Tech. Bull. № 541.

Sigma (1990). Glucose (Trinder). Quantitative, enzymatic determination of glucose in serum or plasma at $505 \mathrm{~nm}$. Sigma chemical Co, St. Louis, MO. Tech Bull $N^{\circ}$ 315.

Steel (R. G. D.) and (J. H.) Torrie. 1980. Principles and Procedures of Statistics : A Biometrical Approach ( $\left.2^{\text {nd }} \mathrm{Ed}\right)$. Mc Graw-Hill Publishing Co, New York.

Van de Ligt (C. P. A.), (M. D.) Lindemann and (G. L.) Cromwell. 2002. Assessment of chromium tripicolinate supplementation and dietary protein level on growth, carcass, and blood criteria in growing pigs. J. Anim. Sci. 80 : 2412 - 2419.

Ward (T. L.), (L. L.) Southern and (T. D.) Bidner. 1997. Interactive effects of dietary chromium tripicolinate and crude protein level in growing-finishing pigs provided inadequate and adequate pen space. J. Anim. Sci. 75 (4) : 1001 - 1008. 